\title{
Amikacin Inhalation Solution
}

National Cancer Institute

\section{Source}

National Cancer Institute. Amikacin Inhalation Solution. NCI Thesaurus. Code C135613.

A solution for inhalation containing the aminog lycoside antibiotic amikacin, with antibacterial activity. Upon aerosolized administration using the Pulmonary Drug Delivery System (PDDS), amikacin irreversibly binds to the 30 S ribosomal subunit of susceptible org anisms, thereby interfering with the activity of the translation initiation complex, which leads to both the misreading of mRNA and the production of non-functional or toxic peptides, and prevents normal protein synthesis. This kills susceptible bacteria. 